\title{
Physiologic and morphologic characters of soybean and Urochloa sp. intercropped under reduced rates of glyphosate
}

\section{Caracteres fisiológicos e morfológicos da soja e da Urochloa sp. consorciados sob doses reduzidas de glifosato}

\begin{abstract}
Jeovane Nascimento SILVA ${ }^{1}$; Leandro Spíndola PEREIRA ${ }^{2}$; Gustavo Dorneles de SOUSA ${ }^{2}$; Gustavo Silva de OLIVEIRA²; Estevam Matheus COSTA3 ; Adriano JAKELAITIS ${ }^{4}$

${ }^{1}$ Mestre em Ciências Agrárias-Agronomia, Doutorando no Programa de Pós-graduação em Ciências Agrárias-Agronomia do
Instituto Federal Goiano Campus Rio Verde, Rio Verde, Goiás, Brasil. Email: jeovaneagro@gmail.com
${ }^{2}$ Graduandos em Agronomia do Instituto Federal Goiano Campus Rio Verde, Rio Verde, Goiás, Brasil. Email:
leandrop629@gmail.com; gustavodorneles7888@gmail.com; gustavosilvadeoliveira147@gmail.com
${ }^{3}$ Mestre em Ciências Agrárias-Agronomia, Programa de Pós-graduação em Ciências Agrárias-Agronomia do Instituto Federal
Goiano Campus Rio Verde, Rio Verde, Goiás, Brasil. Email: estevammcosta@yahoo.com.br
${ }^{4}$ Autor para correspondência - Doutor em Fitotecnia, Diretoria de Pós-Graduação, Pesquisa e Inovação, Instituto Federal Goiano
Campus Rio Verde, Rodovia Sul Goiana, Km 1, Caixa Postal 66, Zona Rural, Rio Verde, Goiás, Brasil, Cep: 75901-970. Email:
adriano.jakelaitis@ifgoiano.edu.br
\end{abstract}

Recebido em: 20-07-2019; Aceito em: 27-04-2020

\begin{abstract}
The intercropping between soybean and Urochloa spp. is an alternative for the use of the area, straw formation, and pasture. In coexistence, the use of herbicide underdoses for forage suppression is required to reduce its interference with soybean plants. The aim of this study was to assess the effects of densities of Urochloa spp. in coexistence with soybean plants and treated or not with glyphosate underdoses. Two experiments with $U$. brizantha and $U$. ruziziensis under coexistence with RR (Roundup Ready $\left.{ }^{\circledR}\right)$ soybean plants were assessed in a randomized block design with four replications. The absence and application of glyphosate underdoses (120 $\mathrm{g}$ a.e. ha $\left.{ }^{-1}\right)$ and five densities of each forage $(0,1,2,4$, and 6 plants per pot) in coexistence with soybean plants were tested in a $2 \times 5$ factorial scheme. The action of glyphosate on forages promoted a reduction in their competitive capacity with soybean plants. Glyphosate decreased the size, tillering, and dry matter accumulation of forages. When glyphosate was not applied, forages interfered negatively in soybean development, especially when in coexistence with $U$. ruziziensis. The increased forage density raises the degree of interference on soybean plants when forages are not treated with glyphosate.
\end{abstract}

\section{Additional keywords: competition; Glycine max (L.); Urochloa brizantha; Urochloa ruziziensis.}

\section{Resumo}

O consórcio entre a cultura da soja e Urochloa spp. é uma alternativa para o aproveitamento de área, formação de palhada e de pastagens. Em convivência, o uso de subdose de herbicidas para supressão da forrageira é requerida para reduzir a competitividade destas sobre as plantas de soja. Objetivou-se avaliar os efeitos de densidades de Urochloa spp. em convivência com plantas de soja, tratada ou não, com subdose de glifosato. Foram avaliados dois ensaios com as forrageiras $U$. brizantha e $U$. ruziziensis, convivendo com plantas de soja RR (Roundup Ready (B), delineados em blocos casualizados com quatro repetições. Testaram-se, em fatorial $2 \times 5$, a ausência e a aplicação de subdose de glifosato $\left(120 \mathrm{~g} \mathrm{e.a} \mathrm{ha}^{-1}\right)$ e cinco densidades de cada forrageira $(0,1,2,4$ e 6 plantas vaso $^{-1}$ ) convivendo com plantas de soja. A ação do glifosato sobre as forrageiras promoveu a redução da capacidade competitiva destas com as plantas de soja. O glifosato diminuiu o porte, o perfilhamento e o acúmulo de massa seca das forrageiras. Quando o glifosato não foi aplicado, as forrageiras interferiram negativamente no desenvolvimento da soja, principalmente quando em convivência com $U$. ruzizizensis. $O$ aumento da densidade das forrageiras eleva o grau de interferência sobre as plantas de soja, quando as forrageiras não são tratadas com glifosato.

\section{Palavras-chave adicionais: competição; Glycine max (L.); Urochloa brizantha; Urochloa ruziziensis.}

\section{Introduction}

Brazil is one of the world's largest soybean producers, mainly due to extensive areas available for its cultivation. The area cultivated with soybean in the $2018 / 19$ agricultural season was approximately 35.874 million hectares, with an average productivity of $3,206.00 \mathrm{~kg} \mathrm{ha}^{-1}$. Soybean is the main agricultural crop produced in Brazil in terms of quantity and sown area (CONAB, 2019). Soybean productivity can be compromised by several factors, especially the interference with weeds (Lamego et al., 2013; Mata et al., 2014). 
The intercropping between soybean and forages has not been used mainly because the forage becomes the main competing with the legume (Machado et al., 2017). Considering that most of the forage species used in intercropping with grain crops are perennial and of $\mathrm{C}_{4}$ photosynthetic metabolism, their coexistence with soybean may become unfavorable to it due to the higher competitive capacity of forages. However, the forage suppressed with soybeanselective herbicides may contribute to the maintenance of its productivity by reducing forage interference (Dan et al., 2011; Tironi et al., 2012). The use of herbicide underdoses in forages of the genus Urochloa may make feasible the intercropping between soybean and forage (Silva et al., 2004; Silva et al., 2005).

Glyphosate is one of the main molecules used in weed management in Roundup Ready ( $R R$ ) soybean because it presents a low acquisition cost and high efficiency in controlling several weeds (Gusmão et al. 2011). The reduction in forage growth may be related to the site of action of glyphosate, as it interferes with the shikimic acid route, which significantly modifies the transport of carbon for this route, which should be directed to plant growth (Nascentes et al., 2015). Therefore, studies on the competition of forage species in relation to $\mathrm{RR}$ soybean are necessary, aiming at developing management strategies and guaranteeing proportions that confer a higher competitive ability to the crop (Agostinetto et al., 2013).

Thus, this study aimed to assess the competitive ability among soybean plants genetically modified to tolerate the glyphosate herbicide in coexistence with five densities of Urochloa ruziziensis and Urochloa brizantha cv. Marandu treated or not with glyphosate.

\section{Material and methods}

The experiment was conducted in a climatized greenhouse located in Rio Verde, GO, Brazil, from September 24 to November 28, 2017. The experimental units consisted of $6 \mathrm{dm}^{-3}$ plastic drilled pots containing a medium textured Oxisol in a 2:1 ratio (soil:sand), and fertilized following the chemical analysis. Fertilization consisted of the application of a dolomitic limestone with a TRNP of $92.5 \%\left(360 \mathrm{mg} \mathrm{dm}^{-3}\right)$, thermophosphate (228 $\left.\mathrm{mg} \mathrm{dm}^{-3}\right)$, and potassium chloride $\left(66.6 \mathrm{mg} \mathrm{dm}^{-3}\right)$.

Two experiments were conducted on the coexistence of forages with soybean, one of them with $U$. ruziziensis and the other with $U$. brizantha $\mathrm{cv}$. Marandu. The experimental design was a randomized block design with four replications. Treatments were arranged in a $2 \times 5$ factorial scheme. The first factor consisted of the absence and application of glyphosate underdose on the forage and the second factor consisted of different densities of forage plants $(0,1,2,4$, and 6 plants per pot). On September 24, 2017, the soybean cultivar Guaiá 7487 RR (7.5) was treated with $62.5 \mathrm{~g}$ chlorantraniliprole $100 \mathrm{~kg}^{-1}$ seeds and inoculated with $80 \mathrm{~g}$ Bradyrhizobium japonicum $50 \mathrm{~kg}^{-1}$ seeds.

Four soybean seeds and eight forage seeds were sown at each experimental unit. Thinning was carried out 9 days after emergence (DAE), leaving two soybean plants in the center of the pot and a variable number of forage plants according to the treatment $(0,1,2,4$, and 6 plants per pot).

The insecticide pyriproxyfen was applied at 9 DAE at a dose of $25 \mathrm{~g} \mathrm{ha}^{-1}$ for controlling Bemisia tabaci race $B$. At 24 DAE, $120 \mathrm{~g} \mathrm{ha}^{-1}$ glyphosate (Lima et al., 2019) was applied by means of a $\mathrm{CO}_{2}$ sprayer equipped with a $2.0 \mathrm{~m}$ boom, nozzles $A X I 110$ 02, and a volume of spray solution of $160 \mathrm{~L} \mathrm{ha}^{-1}$. A wind speed of $1 \mathrm{~m} \mathrm{~s}^{-1}$, relative humidity of $54.7 \%$, and air temperature of $28.3^{\circ} \mathrm{C}$ were registered at application time.

Topdressing fertilization was carried out at 30 DAE with potassium chloride $\left(50 \mathrm{mg} \mathrm{dm}^{-3}\right)$. At the beginning of flowering (36 DAE), micronutrients were applied. Two applications of fungicide were performed. The first application was carried out on October 25 with $70 \mathrm{~g}$ trifloxystrobin $+60 \mathrm{~g}$ prothioconazole and the second application on November 10 with $58.45 \mathrm{~g}$ fluxapiroxade + $116.55 \mathrm{~g}$ pyraclostrobin for controlling Septoria glycines.

Gas exchanges of soybean plants were assessed for registering the photosynthetic $\left(A, \mu \mathrm{mol} \mathrm{m}^{-2} \mathrm{~s}^{-1}\right)$

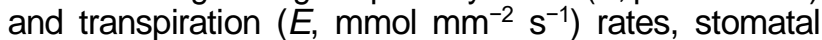
conductance ( $g s, \mathrm{~mol} \mathrm{H}_{2} \mathrm{O} \mathrm{m} \mathrm{m}^{-2} \mathrm{~s}^{-1}$ ), and the internal to external $\mathrm{CO}_{2}$ concentration ratio $(\mathrm{Ci} / \mathrm{Ca})$. These assessments were performed using an automated photosynthesis analyzer model LI-6400XTR (Licor®, Nebraska, USA) with a block temperature of $24^{\circ} \mathrm{C}$ and photon flux density of $1000 \mu \mathrm{mol} \mathrm{m} \mathrm{m}^{-2} \mathrm{~s}^{-1}$. The assessments were performed on the sixth branching of the soybean plant, in the fully expanded leaf at 60 days after the beginning of the coexistence of soybean and forage plants, specifically between 8:30 and 10:30 h.

Plant height, stem dry matter, leaf dry matter, average number of lateral branches and leaves, average stem diameter, leaf area, and root dry matter were determined at 60 DAE of soybean (at harvest time). Plant height was obtained by the average of the two plants of each pot, measured with a ruler graduated in centimeters. The aerial part was cut close to the soil, the number of branches and leaves of each plant was counted, and the length and width of ten leaflets were measured (Richter et al., 2014). The stem diameter of both plants was measured with an automatic caliper. Soybean roots were separated from forage roots, taken to dry in an oven at $65^{\circ} \mathrm{C}$ for 72 hours, and weighed.

Plant height, shoot dry matter, average number of tillers, and root dry matter of forage plants were also measured. Plant height was obtained by the average of the proportion of plants at each pot, measured with a ruler graduated in centimeters. At harvest time, plant shoot was cut close to the ground and the average number of tillers was counted. Forage roots were separated from soybean roots, taken to an oven at $65^{\circ} \mathrm{C}$ for 72 hours, and weighed.

The statistical analyses were performed by using the statistical software SISVAR (version 5.6) (Ferreira, 2014). The data were submitted to analysis of variance $(p<0.05)$ and adjusted to regression models when significant. These models were selected according to the significance, coefficient of determination, simplicity, and biological significance. 


\section{Results and discussion}

No significant interactions were observed for the physiological variables $(A, g s, E$, and $\mathrm{Ci} / \mathrm{Ca})$ measured in soybean plants as a function of the glyphosate underdose application and forage densities (Table 1). An effect of glyphosate was observed on the variables $A, g s$, and $E$ assessed in soybean plants in coexistence with $U$. ruziziensis, confirming a reduction of forage interference capacity (Table 1). On the other hand, a higher forage interference was observed on soybean plants when forage was not treated with glyphosate, with lower values of $A, g s$, and $E$, except for $\mathrm{Ci} / \mathrm{Ca}$ ratio, which did not present statistical difference. Soybean plants in coexistence with $U$. ruziziensis were more affected by the interference in relation to the coexistence with U. brizantha cv. Marandu (Table 1).

Table 1 - Photosynthetic rate $(A)$, stomatal conductance $(g s)$, transpiration rate $(E)$ and the internal to external $\mathrm{CO}_{2}$ concentration ratio $(\mathrm{Ci} / \mathrm{Ca})$ of $\mathrm{RR}$ soybean plants cultivated in coexistence with Urochloa ruziziensis and Urochloa brizantha cv. Marandu treated (TG) or not (NTG) with glyphosate.

\begin{tabular}{|c|c|c|c|c|}
\hline \multicolumn{5}{|c|}{ Experiment $1-$ Coexistence of RR soybean $\times$ Urochloa ruziziensis } \\
\hline \multirow{2}{*}{ Herbicide } & $A$ & $g_{s}$ & $E$ & \multirow{2}{*}{$\mathrm{Ci} / \mathrm{Ca}$} \\
\hline & $\left(\mu \mathrm{mol} \mathrm{m} \mathrm{m}^{-2} \mathrm{~s}^{-1}\right)$ & $\left(\mathrm{mol} \mathrm{m}^{-2} \mathrm{~s}^{-1}\right)$ & $\left(\mathrm{mmol} \mathrm{m}^{-2} \mathrm{~s}^{-1}\right)$ & \\
\hline NTG & $10.02 \mathrm{~b}$ & $0.19 \mathrm{~b}$ & $3.61 \mathrm{~b}$ & $0.75 \mathrm{a}$ \\
\hline TG & $13.15 \mathrm{a}$ & $0.27 \mathrm{a}$ & $4.76 \mathrm{a}$ & $0.77 \mathrm{a}$ \\
\hline \multicolumn{5}{|c|}{ Density (plants per pot) } \\
\hline 0 & 13.97 & 0.28 & 5.00 & 0.76 \\
\hline 1 & 13.65 & 0.28 & 4.88 & 0.76 \\
\hline 2 & 9.74 & 0.18 & 3.49 & 0.76 \\
\hline 4 & 10.55 & 0.21 & 3.94 & 0.76 \\
\hline 6 & 10.01 & 0.20 & 3.62 & 0.77 \\
\hline Regression & $\hat{Y}=\bar{Y}=11.58$ & $\hat{Y}=\bar{Y}=0.23$ & $\hat{\mathrm{Y}}=\overline{\mathrm{Y}}=4.19$ & $\hat{\mathrm{Y}}=\overline{\mathrm{Y}}=0.76$ \\
\hline CV (\%) & 36.35 & 41.42 & 34.12 & 4.60 \\
\hline \multicolumn{5}{|c|}{ Experiment 2 - Coexistence of RR soybean $\times$ Urochloa brizantha cv. Marandu } \\
\hline Herbicide & $A$ & $g_{s}$ & $E$ & \multirow{2}{*}{$\mathrm{Ci} / \mathrm{Ca}$} \\
\hline meroiciae & $\left(\mu \mathrm{mol} \mathrm{m} \mathrm{m}^{-2} \mathrm{~s}^{-1}\right)$ & $\left(\mathrm{mol} \mathrm{m}^{-2} \mathrm{~s}^{-1}\right)$ & $\left(\mathrm{mmol} \mathrm{m} \mathrm{m}^{-2} \mathrm{~s}^{-1}\right)$ & \\
\hline NTG & $10.56 \mathrm{a}$ & $0.23 \mathrm{a}$ & $4.21 \mathrm{a}$ & $0.77 \mathrm{a}$ \\
\hline TG & $10.77 \mathrm{a}$ & $0.23 \mathrm{a}$ & $4.36 \mathrm{a}$ & $0.77 \mathrm{a}$ \\
\hline \multicolumn{5}{|c|}{ Density (plants per pot) } \\
\hline 0 & 11.29 & 0.24 & 4.43 & 0.78 \\
\hline 1 & 10.84 & 0.22 & 4.14 & 0.75 \\
\hline 2 & 11.04 & 0.25 & 4.46 & 0.77 \\
\hline 4 & 9.34 & 0.20 & 3.92 & 0.77 \\
\hline 6 & 10.82 & 0.23 & 4.49 & 0.78 \\
\hline Regression & $\hat{Y}=\bar{Y}=10.67$ & $\hat{Y}=\bar{Y}=0.23$ & $\hat{Y}=\bar{Y}=4.29$ & $\hat{\mathrm{Y}}=\overline{\mathrm{Y}}=0.77$ \\
\hline CV (\%) & 40.99 & 52.18 & 39.58 & 5.36 \\
\hline
\end{tabular}

* Means followed by the same letter in the rows do not differ statistically by the F-test $(p<0.05)$.

Competitive capacity is determined by aggressiveness characteristics of each competing species in the environment of the main crop (Jakelaitis et al., 2010). Thus, soybean plants in coexistence with $U$. ruziziensis suppressed by glyphosate were favored with a higher photosynthetic efficiency (Bastini et al., 2016). Regardless of density and use of glyphosate in $U$. brizantha $\mathrm{cv}$. Marandu, gas exchanges of soybean plants in coexistence with forage species were not affected (Table 1). However, a correct management of forage can minimize the competitive potential with soybean (Machado et al., 2017) since, in other environmental conditions, $U$. brizantha in coexistence reduced soybean productive capacity (Mata et al., 2014; Saraiva et al., 2014).

For plant height $(\mathrm{PH})$, stem diameter (SD), average number of leaves (ANL), average number of lateral branches (ANLB), leaf dry matter (LDM), stem dry matter (SDM), and leaf area (LA), interactions were observed between the density of $U$. ruziziensis and glyphosate (Table 2). The suppression of $U$. ruziziensis by glyphosate benefited PH, SD, LDM, SDM, and LA in soybean plants in coexistence at densities of 4 and 6 forage plants per pot, as well as ANL and ANLB at densities of 2, 4, and 6 plants per pot, when compared to plots not treated with glyphosate (Table 2). 
Table 2 - Plant height (PH), stem diameter (SD), average number of leaves (ANL), average number of lateral branches (ANLB), leaf dry matter (LDM), stem dry matter (SDM), root dry matter (RDM), and leaf area (LA) of RR soybean plants cultivated in coexistence with densities of Urochloa ruziziensis treated (TG) or not (NTG) with glyphosate.

\begin{tabular}{|c|c|c|c|c|c|c|c|c|}
\hline \multicolumn{9}{|c|}{ Experiment $1-$ Coexistence of RR soybean $\times$ Urochloa ruziziensis } \\
\hline \multirow{2}{*}{ Herbicide } & \multicolumn{5}{|c|}{ Density (plants per pot) } & \multirow{2}{*}{ Mean } & \multirow{2}{*}{ Regression } & \multirow{2}{*}{$\mathrm{R}^{2}$} \\
\hline & 0 & 1 & 2 & 4 & 6 & & & \\
\hline \multicolumn{9}{|c|}{$\mathrm{PH}(\mathrm{cm})$} \\
\hline NTG & $32.06 \mathrm{a}^{1}$ & $28.33 \mathrm{a}$ & $26.60 \mathrm{a}$ & $23.95 \mathrm{~b}$ & $22.04 \mathrm{~b}$ & 26.59 & $\hat{Y}=30.6502-1.5597 x$ & $93.05^{*}$ \\
\hline TG & $30.55 \mathrm{a}$ & $26.94 \mathrm{a}$ & $26.84 \mathrm{a}$ & $28.39 \mathrm{a}$ & $30.25 \mathrm{a}$ & 28.59 & $\hat{\mathrm{Y}}=\overline{\mathrm{Y}}=26.60$ & -- \\
\hline CV (\%) & \multicolumn{8}{|c|}{10.17} \\
\hline \multicolumn{9}{|c|}{$\mathrm{SD}(\mathrm{mm})$} \\
\hline NTG & $6.55 \mathrm{a}$ & $5.11 \mathrm{a}$ & $4.71 \mathrm{a}$ & $4.26 \mathrm{~b}$ & $3.89 \mathrm{~b}$ & 4.91 & $\hat{Y}=5.897-0.381 x$ & $80.00^{*}$ \\
\hline TG & $5.64 \mathrm{a}$ & $5.30 \mathrm{a}$ & $5.14 \mathrm{a}$ & $5.55 \mathrm{a}$ & $5.65 \mathrm{a}$ & 5.46 & $\hat{\mathrm{Y}}=\overline{\mathrm{Y}}=5.46$ & -- \\
\hline CV (\%) & & & & & 12.44 & & & \\
\hline \multicolumn{9}{|c|}{ ANL } \\
\hline NTG & $48.38 \mathrm{a}$ & $27.13 \mathrm{a}$ & $24.88 \mathrm{~b}$ & $16.25 \mathrm{~b}$ & $18.38 \mathrm{~b}$ & 27.00 & $\hat{\mathrm{Y}}=48.3787 /\left(1+(\mathrm{x} / 1.7207)^{0.5086}\right.$ & $97.95^{\star}$ \\
\hline TG & $41.88 \mathrm{a}$ & $29.75 \mathrm{a}$ & $38.75 \mathrm{a}$ & $34.38 \mathrm{a}$ & $39.50 \mathrm{a}$ & 36.85 & $\hat{\mathrm{Y}}=\overline{\mathrm{Y}}=36.85$ & -- \\
\hline $\mathrm{CV}(\%)$ & \multicolumn{8}{|c|}{24.61} \\
\hline \multicolumn{9}{|c|}{ ANLB } \\
\hline NTG & $10.88 \mathrm{a}$ & $8.38 \mathrm{a}$ & $7.13 \mathrm{~b}$ & $5.88 \mathrm{~b}$ & $5.25 b$ & 7.50 & $\hat{Y}=9.72-0.856 x$ & $85.13^{*}$ \\
\hline TG & $11.00 \mathrm{a}$ & $9.25 \mathrm{a}$ & $9.50 \mathrm{a}$ & $10.00 \mathrm{a}$ & $9.88 \mathrm{a}$ & 9.93 & $\hat{\mathrm{Y}}=\overline{\mathrm{Y}}=9.93$ & -- \\
\hline CV (\%) & & & & & & & & \\
\hline \multicolumn{9}{|c|}{$\frac{16.95}{\text { LDM (g per pot) }}$} \\
\hline NTG & $3.58 \mathrm{a}$ & $1.76 \mathrm{a}$ & $1.52 \mathrm{a}$ & $0.82 \mathrm{~b}$ & $0.80 \mathrm{~b}$ & 1.70 & $\hat{Y}=3.5798 /\left(1+(x / 1.0496)^{0.7516}\right.$ & $99.04^{*}$ \\
\hline TG & $3.16 \mathrm{a}$ & $1.97 \mathrm{a}$ & $2.25 \mathrm{a}$ & $2.53 \mathrm{a}$ & $2.86 \mathrm{a}$ & 2.55 & $\hat{\mathrm{Y}}=\overline{\mathrm{Y}}=2.55$ & -- \\
\hline CV (\%) & & & & & $31.4 \varepsilon$ & & & \\
\hline \multicolumn{9}{|c|}{ SDM (g per pot) } \\
\hline NTG & $6.57 \mathrm{a}$ & $3.73 \mathrm{a}$ & $3.20 \mathrm{a}$ & $2.01 \mathrm{~b}$ & $1.91 \mathrm{~b}$ & 3.48 & $\hat{\mathrm{Y}}=6.5637 /\left(1+(x / 1.5691)^{0.7157}\right.$ & $99.31^{*}$ \\
\hline TG & $4.98 \mathrm{a}$ & $3.96 \mathrm{a}$ & $3.82 \mathrm{a}$ & $4.65 \mathrm{a}$ & $5.18 \mathrm{a}$ & 4.52 & $\hat{\mathrm{Y}}=\overline{\mathrm{Y}}=4.52$ & -- \\
\hline CV (\%) & & & & & 28.62 & & & \\
\hline \multicolumn{9}{|c|}{ RDM (g per pot) } \\
\hline NTG & 4.05 & 2.91 & 3.20 & 4.43 & 4.02 & 3.71 & $\hat{Y}-\bar{Y}-370$ & \\
\hline TG & 5.10 & 3.06 & 3.01 & 3.33 & 3.87 & 3.67 & $Y=Y=3.70$ & -- \\
\hline CV (\%) & \multicolumn{8}{|c|}{31.76} \\
\hline \multicolumn{9}{|c|}{$\mathrm{LA}\left(\mathrm{cm}^{2}\right)$} \\
\hline NTG & $1681.43 \mathrm{a}$ & $854.20 \mathrm{a}$ & $688.32 \mathrm{a}$ & $395.81 \mathrm{~b}$ & $336.60 \mathrm{~b}$ & 791.27 & $\hat{Y}=1680.31 /\left(1+(x / 1.1105)^{0.8303}\right.$ & $99.64^{*}$ \\
\hline TG & $1488.56 \mathrm{a}$ & $896.22 \mathrm{a}$ & $1039.91 \mathrm{a}$ & $1018.77 \mathrm{a}$ & $1174.67 \mathrm{a}$ & 1123.63 & $\hat{Y}=\bar{Y}=1023.63$ & -- \\
\hline CV (\%) & \multicolumn{8}{|c|}{33.16} \\
\hline
\end{tabular}

${ }^{1}$ Means followed by the same letter in the rows do not differ statistically by the F-test $(p<0.05) .{ }^{*}$ Significant by the F-test $(p<0.05)$.

Soybean plants of the cultivar Guaiá 7487 RR (7.5) have a low size, which makes easier the growth of competing plants, especially Brachiaria (Syn. Urochloa), which has a fast growth (Portes et al., 2017), justifying the use of glyphosate as a forage growth inhibitor. No interaction was observed between the tested factors for root dry matter (RDM) of soybean (Table 2).

When $U$. ruziziensis was treated with glyphosate, no effect of plant density was observed on the variables assessed in soybean plants (Table 2). Untreated, the increased density of $U$. ruziziensis led to linear reductions of $1.55 \mathrm{~cm}, 0.38 \mathrm{~mm}$, and 0.85 in $\mathrm{PH}$, $\mathrm{SD}$, and ANLB, respectively, with the addition of a forage plant in coexistence with soybean (Table 2). For ANL, LDM, SDM, and LA, the reductions were explained by the three-parameter sigmoidal model, in which densities that provided a $50 \%$ reduction in response variables were $1.72,1.05,1.57$, and 1.11 plants of $U$. ruziziensis in coexistence with soybean, respectively, demonstrating that soybean plants were susceptible to the interference imposed by the forage plants (Table 2).

These results are supported by Brighenti et al. (2011), who verified variability in the tolerance of Urochloa species to glyphosate and observed that $U$. ruziziensis was more sensitive in relation to $U$. decumbens and U. brizantha. Galon et al. (2011) reported that might occur damage to crop and weed growth when competing in a given community, with a peculiar competitive effect on each species. Morphological and physiological differences and resource extraction capacity by $U$. ruziziensis may have contributed to its interference on soybean. As an example, the fasciculate root system of $U$. ruziziensis allows the plant to more easily explore soil volume when compared to plants with a pivoting root system such as soybean (Machado et al., 
2017). In addition, studies conducted with U. ruziziensis have shown allelopathic inhibitory activity in soybean (Nepomuceno et al., 2019), mainly due the protodioscin that is compound that has a significant phytotoxic effect (Nepomuceno et al., 2017). Thus, the suppression of $U$. ruziziensis by the glyphosate underdose also contributed to the reduction of allelopathic capacity on soybean plants.

In coexistence with $U$. brizantha cv. Marandu, significant interactions were observed between the use of herbicide and forage densities for SD, ANL, ANLB, LDM, SDM, RDM, and LA, except for PH of soybean plants (Table 3). Within the tested densities, the use of glyphosate was necessary to increment the variables SD, LDM, SDM, and RDM of soybean at densities of 4 and 6 plants of $U$. brizantha per pot in coexistence with soybean, and ANL and ANLB at a density of 6 plants per pot (Table 3). In these treatments, the absence of suppression of forage growth affected soybean growth. Considering the coexistence of soybean with forage plants without the suppression promoted by the herbicide, linear reductions $0.18 \mathrm{~mm}, 3.76,0.25$, and $0.34 \mathrm{~g}$ were observed for SD, ANL, LDM, and RDM, respectively (Table 3 ). Thus, by contrasting forage competition with soybean plants in both experiments and considering the number of soybean variables affected by competition, the models that explain the biological phenomenon (sigmoidal and linear), and the regression models, we can conclude that $U$. ruziziensis interfered more with soybean than $U$. brizantha cv. Marandu (Tables 2 and 3).

Table 3 - Plant height (PH), stem diameter (SD), average number of leaves (ANL), average number of lateral branches (ANLB), leaf dry matter (LDM), stem dry matter (SDM), root dry matter (RDM), and leaf area (LA) of RR soybean plants cultivated in coexistence with densities of Urochloa brizantha cv. Marandu treated (TG) or not (NTG) with glyphosate.

\begin{tabular}{|c|c|c|c|c|c|c|c|c|}
\hline \multirow{3}{*}{ Herbicide } & \multicolumn{8}{|c|}{ Experiment $2-$ Coexistence of RR soybean $\times$ Urochloa brizantha cv. Marandu } \\
\hline & \multicolumn{5}{|c|}{ Density (plants per pot) } & \multirow{2}{*}{ Mean } & \multirow{2}{*}{ Regression } & \multirow{2}{*}{$\mathrm{R}^{2}$} \\
\hline & 0 & 1 & 2 & 4 & 6 & & & \\
\hline \multicolumn{9}{|c|}{$\mathrm{PH}(\mathrm{cm})$} \\
\hline NTG & 30.13 & 30.96 & 29.82 & 29.51 & 29.74 & $29.74 \mathrm{a}^{1}$ & \multirow{2}{*}{$\hat{Y}=\bar{Y}=29.23$} & \multirow{2}{*}{--} \\
\hline TG & 27.27 & 27.45 & 28.90 & 30.98 & 28.70 & $28.70 \mathrm{a}$ & & \\
\hline CV (\%) & \multicolumn{8}{|c|}{8.04} \\
\hline \multicolumn{9}{|c|}{$\mathrm{SD}(\mathrm{mm})$} \\
\hline NTG & $5.27 \mathrm{a}$ & $5.48 \mathrm{a}$ & $5.25 \mathrm{a}$ & $4.53 \mathrm{~b}$ & $4.43 \mathrm{~b}$ & 4.99 & $\hat{Y}=5.4687-0.1812 x$ & $84.12^{*}$ \\
\hline TG & $5.47 \mathrm{a}$ & $5.36 \mathrm{a}$ & $5.35 \mathrm{a}$ & $5.97 \mathrm{a}$ & $6.28 \mathrm{a}$ & 5.68 & $\hat{\mathrm{Y}}=\overline{\mathrm{Y}}=5.68$ & -- \\
\hline $\mathrm{CV}(\%)$ & \multicolumn{8}{|c|}{10.71} \\
\hline \multicolumn{9}{|c|}{ ANL } \\
\hline NTG & $39.12 \mathrm{a}$ & $45.50 \mathrm{a}$ & $38.62 \mathrm{a}$ & $27.50 \mathrm{a}$ & $21.12 b$ & 34.37 & $\hat{Y}=44.1670-3.7662 x$ & $84.98^{*}$ \\
\hline TG & $44.12 \mathrm{a}$ & $44.87 \mathrm{a}$ & $32.37 \mathrm{a}$ & $39.87 \mathrm{a}$ & $45.25 \mathrm{a}$ & 41.30 & $\hat{\mathrm{Y}}=\overline{\mathrm{Y}}=41.30$ & -- \\
\hline CV (\%) & \multicolumn{8}{|c|}{24.45} \\
\hline \multicolumn{9}{|c|}{ ANLB } \\
\hline NTG & $9.25 \mathrm{a}$ & $10.00 \mathrm{a}$ & $9.87 \mathrm{a}$ & $8.50 \mathrm{a}$ & $7.37 \mathrm{~b}$ & 9.00 & $\hat{\mathrm{Y}}=\overline{\mathrm{Y}}=9.00$ & -- \\
\hline TG & $10.12 \mathrm{a}$ & $9.62 \mathrm{a}$ & $9.00 \mathrm{a}$ & $9.75 \mathrm{a}$ & $10.50 \mathrm{a}$ & 9.80 & $\hat{Y}=\bar{Y}=9.80$ & -- \\
\hline CV (\%) & \multicolumn{8}{|c|}{14.07} \\
\hline \multicolumn{9}{|c|}{ LDM (g per pot) } \\
\hline NTG & $2.59 \mathrm{a}$ & $2.91 \mathrm{a}$ & $2.69 \mathrm{a}$ & $1.78 \mathrm{~b}$ & $1.41 \mathrm{~b}$ & 2.28 & $\hat{Y}=2.9242-0.2464 x$ & $84.51^{*}$ \\
\hline TG & $3.17 \mathrm{a}$ & $2.80 \mathrm{a}$ & $2.30 \mathrm{a}$ & $3.02 \mathrm{a}$ & $3.96 \mathrm{a}$ & 3.05 & $\hat{\mathrm{Y}}=\overline{\mathrm{Y}}=3.05$ & -- \\
\hline CV (\%) & \multicolumn{8}{|c|}{27.67} \\
\hline \multicolumn{9}{|c|}{ SDM (g per pot) } \\
\hline NTG & $4.66 \mathrm{a}$ & $5.15 \mathrm{a}$ & $5.00 \mathrm{a}$ & $3.77 \mathrm{~b}$ & $3.62 \mathrm{~b}$ & 4.44 & $\hat{\mathrm{Y}}=\overline{\mathrm{Y}}=4.44$ & -- \\
\hline TG & $5.05 \mathrm{a}$ & $4.15 \mathrm{a}$ & $4.51 \mathrm{a}$ & $5.06 \mathrm{a}$ & $6.04 \mathrm{a}$ & 4.96 & $\hat{Y}=\bar{Y}=4.96$ & -- \\
\hline CV (\%) & \multicolumn{8}{|c|}{18.53} \\
\hline \multicolumn{9}{|c|}{ RDM (g per pot) } \\
\hline NTG & $3.28 \mathrm{a}$ & $2.40 \mathrm{a}$ & $2.36 \mathrm{a}$ & $1.43 \mathrm{~b}$ & $1.17 \mathrm{~b}$ & 2.13 & $\hat{Y}=3.0101-0.3363 x$ & $91.81^{*}$ \\
\hline $\mathrm{TG}$ & $4.36 \mathrm{a}$ & $3.20 \mathrm{a}$ & $2.70 \mathrm{a}$ & $3.91 \mathrm{a}$ & $4.08 \mathrm{a}$ & 3.65 & $\hat{\mathrm{Y}}=\overline{\mathrm{Y}}=2.13$ & -- \\
\hline CV (\%) & \multicolumn{8}{|c|}{29.57} \\
\hline \multicolumn{9}{|c|}{$\mathrm{LA}\left(\mathrm{cm}^{2}\right)$} \\
\hline NTG & $1237.69 \mathrm{a}$ & $1200.99 a$ & $1229.88 \mathrm{a}$ & $780.18 \mathrm{a}$ & $633.37 \mathrm{~b}$ & 1016.42 & $\hat{Y}=\bar{Y}=1016.42$ & -- \\
\hline TG & $1337.83 \mathrm{a}$ & $1164.99 \mathrm{a}$ & 999.89 a & $1269.49 \mathrm{a}$ & $1773.27 \mathrm{a}$ & 1309.09 & $\hat{Y}=\bar{Y}=1309.09$ & -- \\
\hline CV (\%) & & & & & 32.42 & & & \\
\hline
\end{tabular}


Soybean plants also have a competitive capacity as some weeds, as observed by Forte et al. (2017) for the varieties BMX Alvo RR and Fundacep 55RR, which showed a higher competitive capacity when compared to Bidens pilosa and Euphorbia heterophylla. However, the competitive capacity of
Urochloa plantaginea was lower and that of Commelina benghalensis was similar to soybean (Dias et al., 2010). In coexistence with soybean, significant interactions were observed for $\mathrm{PH}, \mathrm{SDM}$, and RDM of plants of $U$. ruziziensis (Table 4).

Table 4 - Plant height (PH), number of tillers per plant (NTP). shoot dry matter (SDM). and root dry matter (RDM) of different plant densities of Urochloa ruziziensis and Urochloa brizantha cv. Marandu competing with RR soybean treated (TG) or not (NTG) with glyphosate.

\begin{tabular}{|c|c|c|c|c|c|c|c|}
\hline \multicolumn{8}{|c|}{ Experiment $1-$ Coexistence of RR soybean $\times$ Urochloa ruziziensis } \\
\hline \multirow{2}{*}{ Herbicide } & \multicolumn{4}{|c|}{ Density (plants per pot) } & \multirow{2}{*}{ Mean } & \multirow{3}{*}{ Regression } & \multirow{2}{*}{$\mathrm{R}^{2}$} \\
\hline & \multirow{2}{*}{\multicolumn{6}{|c|}{$\mathrm{PH}(\mathrm{cm})$}} & \\
\hline & & & & & & & \\
\hline NTG & $42.20 \mathrm{a}^{1}$ & $33.75 \mathrm{a}$ & $31.58 \mathrm{a}$ & $31.26 \mathrm{a}$ & 34.70 & \multirow{3}{*}{$\begin{array}{c}\hat{Y}=31.3528+48.7584^{\exp -1.5032 x} \\
\hat{Y}=\bar{Y}=17.03\end{array}$} & \multirow{3}{*}{$\begin{array}{c}99.97^{*} \\
--\end{array}$} \\
\hline TG & $13.30 \mathrm{~b}$ & $19.64 b$ & $17.83 \mathrm{~b}$ & $17.34 \mathrm{~b}$ & 17.03 & & \\
\hline CV (\%) & \multirow{2}{*}{\multicolumn{7}{|c|}{15,07}} \\
\hline & & & & & & & \\
\hline NTG & 4.25 & 3.13 & 3.13 & 2.79 & $3.32 \mathrm{a}$ & \multirow{2}{*}{$\hat{Y}=\bar{Y}=2.49$} & \multirow{2}{*}{--} \\
\hline TG & 1.75 & 1.63 & 1.50 & 1.79 & $1.67 \mathrm{~b}$ & & \\
\hline CV (\%) & \multirow{2}{*}{\multicolumn{7}{|c|}{$\begin{array}{r}25.13 \\
\text { SDM (g per pot) }\end{array}$}} \\
\hline SDM (g per pot) & & & & & & & \\
\hline NTG & $2.30 \mathrm{a}$ & $2.39 \mathrm{a}$ & $3.91 \mathrm{a}$ & $4.86 \mathrm{a}$ & 3.36 & $\hat{Y}=1.5749+0.5509 x$ & $97.11^{*}$ \\
\hline TG & $0.06 \mathrm{~b}$ & $0.15 b$ & $0.36 \mathrm{~b}$ & $0.81 \mathrm{~b}$ & 0.34 & $\hat{Y}=\bar{Y}=0.34$ & -- \\
\hline CV (\%) & \multicolumn{7}{|c|}{28.03} \\
\hline \multicolumn{8}{|c|}{ RDM (g per pot) } \\
\hline NTG & $1.04 \mathrm{a}$ & $1.71 \mathrm{a}$ & $2.77 \mathrm{a}$ & $3.69 \mathrm{a}$ & 2.30 & $\hat{\mathrm{Y}}=0.5993+0.5245 \mathrm{x}$ & $99.53^{*}$ \\
\hline TG & $0.02 b$ & $0.10 \mathrm{~b}$ & $0.24 b$ & $0.52 \mathrm{~b}$ & 0.22 & $\hat{\mathrm{Y}}=\overline{\mathrm{Y}}=0.22$ & -- \\
\hline CV (\%) & \multicolumn{7}{|c|}{46.21} \\
\hline & Exp & ment $2-($ & existence & ff RR so & an $\times$ Uroc & brizantha cv. Marandu & \\
\hline & & & & & & & \\
\hline NTG & 48.30 & 40.68 & 39.41 & 37.91 & $41.57 \mathrm{a}$ & \multirow{2}{*}{$\hat{Y}=39.5772+2.1041 x$} & \multirow{2}{*}{$76.75^{\star}$} \\
\hline TG & 31.88 & 23.64 & 20.68 & 18.07 & $23.46 \mathrm{~b}$ & & \\
\hline CV (\%) & \multirow{2}{*}{\multicolumn{7}{|c|}{21.98}} \\
\hline & & & & & & & \\
\hline NTG & 4.00 & 4.25 & 3.56 & 3.37 & $3.80 \mathrm{a}$ & \multirow{2}{*}{$\hat{Y}=3.4205+0.1727 x$} & \multirow{2}{*}{$76.72^{*}$} \\
\hline TG & 2.75 & 1.87 & 1.31 & 1.75 & $1.92 \mathrm{~b}$ & & \\
\hline CV (\%) & \multicolumn{7}{|c|}{20.45} \\
\hline \multicolumn{8}{|c|}{ SDM (g per pot) } \\
\hline NTG & $2.51 \mathrm{a}$ & $3.17 \mathrm{a}$ & $5.34 \mathrm{a}$ & $6.00 \mathrm{a}$ & 4.26 & $\hat{Y}=1.859+0.7383 x$ & $95.29^{*}$ \\
\hline TG & $0.47 \mathrm{~b}$ & $0.77 \mathrm{~b}$ & $0.65 b$ & $0.79 \mathrm{~b}$ & 0.67 & $\hat{\mathrm{Y}}=\overline{\mathrm{Y}}=0.67$ & -- \\
\hline CV (\%) & \multicolumn{7}{|c|}{24.03} \\
\hline \multicolumn{8}{|c|}{ RDM (g per pot) } \\
\hline NTG & $3.12 \mathrm{a}$ & $4.09 \mathrm{a}$ & $6.21 \mathrm{a}$ & $7.52 \mathrm{a}$ & 5.24 & $\hat{Y}=2.3292+0.8954 x$ & $98.89^{*}$ \\
\hline TG & $0.27 b$ & $1.24 \mathrm{~b}$ & $0.52 \mathrm{~b}$ & $0.62 \mathrm{~b}$ & 0.67 & $\hat{\mathrm{Y}}=\overline{\mathrm{Y}}=0.66$ & -- \\
\hline CV (\%) & & & & & 35.48 & & \\
\hline
\end{tabular}

${ }^{1}$ Means followed by the same letter in the rows do not differ statistically by the F-test $(p<0.05) .{ }^{*}$ Significant by the F-test $(p<0.05)$.

For the number of tillers per plant (NTP), only the effects of glyphosate suppression reduced the value of this variable in the treated plants (Table 4). Glyphosate at a dose of $120 \mathrm{~g} \mathrm{ha}^{-1}$ affected PH, SDM, and RDM of the forage, reducing its competitive capacity with soybean. These results are in accordance with Concenço et al. (2014), who stated that doses above $96 \mathrm{~g} \mathrm{ha}^{-1}$ of glyphosate are sufficient to reduce fresh and dry matter and cause tiller mortality in Panicum maximum. In general, without suppression by glyphosate, a linear increase was observed in the dry matter accumulation of $U$. ruziziensis from the higher acquisition of environmental resources as density increased, resulting in a reduction of growth variables observed in soybean (Tables 2 and 4 ).

For U. brizantha cv. Marandu, significant interactions were observed between the use of glyphosate and plant density for SDM and RDM, with no interactions for PH and NTP (Table 4). For PH and NTP, only isolated effects were observed. In this case, glyphosate reduced the values of both variables, with reductions of $2.1 \mathrm{~cm}$ and of 0.17 tiller per plant in the pots. Considering the effects within each forage density, glyphosate was effective in suppressing SDM and RDM of forages 
in relation to the absence of application (Table 4). In the absence of glyphosate, linear increases were observed in the accumulation of SDM and RDM of the order of 0.73 and $0.89 \mathrm{~g}$ per pot, resulting in a higher forage competitive capacity in relation to soybean as density increased (Table 3).

\section{Conclusions}

Glyphosate at a dose of $120 \mathrm{~g} \mathrm{ha}^{-1}$ suppresses growth of grasses and reduces its competitive capacity with soybeans, even with increasing plants density.

When not suppressed with glyphosate, forages at the highest densities (4 and 6 plants per pot) affect the growth of soybean plants in coexistence, being this effect more pronounced with $U$. ruziziensis.

\section{Acknowledgments}

This study was carried out with the support of the Coordination for the Improvement of Higher Education Personnel, Brazil (CAPES) under the financing code 001 and the Goiano Federal Institute, Rio Verde Campus.

\section{References}

Agostinetto D, Camponogara LF, Vargas L, Markus C, Oliveira E (2013) Habilidade competitiva relativa de milhã em convivência com arroz irrigado e soja. Pesquisa Agropecuária Brasileira 48(10): 1315-1322.

Bastini MO, Lamego FP, Agostinetto D, Langaro AC, Silva DC (2016) Competitividade relativa de cultivares de soja com capim-arroz. Bragantia 75(4): 435-445.

Brighenti AM, Sobrinho FS, Rocha WSD, Martins CE, Demartini D, Costa TR (2011) Suscetibilidade diferencial de espécies de braquiária ao herbicida glifosato. Pesquisa Agropecuária Brasileira 46(10): 1241-1246.

CONAB - Companhia Nacional de Abastecimento (2019) Acompanhamento da Safra Brasileira: 2o levantamento de grãos. Safra 2018/2019. Brasília: CONAB. 110p.

Concenço G, Machado LAZ, Galon L, Correria IVT, Santos AS, Palharini WG (2014) Supressão química do crescimento de Panicum maximum cv. Aruana, cultivado em consórcio com a cultura da soja. Revista Agrarian 7(24): 176-188.

Dan HA, Barroso ALL, Dan LGM, Procópio SO, Oliveira Júnior RS, Constantin J, Feldkircher C (2011) Supressão imposta pelo mesotrione a Brachiaria brizantha em sistema de integração lavoura-pecuária. Planta Daninha 29(4): 861-867.

Dias ACR, Carvalho SJP, Marcolini LW, Melo MSC, Christoffoleti PJ (2010) Competitividade de capimmarmelada ou trapoeraba com soja. Planta Daninha 28(3): 515-522.
Ferreira DF (2014) Sisvar: a guide for its bootstrap procedures in multiple comparisons. Ciência e Agrotecnologia 38(2):109-112.

Forte CT, Basso FJM, Galon L, Agazzi LR, Nonemacher F, Concenço G (2017) Habilidade competitiva de cultivares de soja transgênica convivendo com plantas daninhas. Revista Brasileira de Ciências Agrárias 12(2): 185-193.

Galon L, Tironi SP, Rocha PRR, Concenço G, Silva AF, Vargas L, Silva AA, Ferreira EA, Minella E, Soares ER, Ferreira FA (2011) Habilidade competitiva de cultivares de cevada convivendo com azevém. Planta Daninha 29(4): 771-781.

Gusmão GA, Rondon Neto RM, Yamashita OM (2011) Deriva simulada de glyphosate em plantas jovens de jenipapo (Genipa americana L.). Revista Brasileira de Herbicidas 10(1): 13-19.

Jakelaitis A, Gil JO, Simões LS, Souza KV, Ludtke J (2010) Efeitos da interferência de plantas daninhas na implantação de pastagem de Brachiaria brizantha. Revista Caatinga 23(1): 8-14.

Lamego FP, Ruchel Q, Kaspary TE, Gallon M, Basso CJ, Santi AL (2013) Habilidade competitiva de cultivares de trigo com plantas daninhas. Planta Daninha 31(3): 521-531.

Lima SF, Pereira LS, Sousa GDD, Oliveira, GSD, Jakelaitis A (2019) Supressão de Urochloa brizantha e $U$. ruziziensis por subdoses de glyphosate. Revista Caatinga, 32(3): 581-589.

Machado LAZ, Cecato U, Comunello E, Concenço G, Ceccon $G$ (2017) Estabelecimento de forrageiras perenes em consórcio com soja, para sistemas integrados de produção agropecuária. Pesquisa Agropecuária Brasileira 52(7): 521-529.

Mata JF, Dotto MC, Erasmo EAL, Siebeneichler SC, Santos GR, Bianco S (2014) Crescimento de Brachiaria brizantha cv. BRS Piatã consorciada com a cultura da soja sob diferentes densidades e épocas de semeadura. Revista Agroambiente 8(3): 377-386.

Nascentes RF, Fagan EB, Soares LH, Oliveira CB, Brunelli MC (2015) Hormesis de glyphosate em Bachiaria brizantha cv. Marandu. Cerrado Agrociências 6: 55-64.

Nepomuceno M, Chinchilla N, Varela RM, Molinillo JM, Lacret R, Alves PL, Macias FA (2017). Chemical evidence for the effect of Urochloa ruziziensis on glyphosate-resistant soybeans. Pest Management Science 73(10): 2071-2078. 
Nepomuceno MP, Silva BP, Giancotti PRF, Pereira FCM, Alves PLCA (2019). Urochloa ruziziensis desiccation, straw quantity and position on nodulation and production of soybean 'M-SOY 7908 RR'. Planta Daninha 37: e019166586.

Portes TA, Ferreira AM, Peixoto MM, Melo HC (2017) Growth and senescence of Urochloa brizantha under Brazilian Cerrado conditions. African Journal of Agricultural Research 12(34): 2625-2632.

Richter GL, Zanon Júnior A, Streck NA, Guedes JVC, Kräulich B, Rocha TSMD, Winck JEM, Cera JC (2014) Estimativa da área de folhas de cultivares antigas e modernas de soja por método não destrutivo. Bragantia, 73(4), 416-425.

Saraiva AS, Dornelas BF, Silva JIC, Erasmo EAL, Dornelas DF, Mata JF, Sarmento RA (2014) Soja M8527 RR consorciada com braquiária piatã em diferentes densidades e épocas de semeadura. Planta Daninha 32(3): 497-505.
Silva AC, Ferreira LR, Silva AD, Paiva TWB, Sediyama CS (2004) Efeitos de doses reduzidas de fluazifop-pbutil no consórcio entre soja e Brachiaria brizantha. Planta Daninha 22(3): 429-435.

Silva AC, Ferreira LR, Silva AD, Belo AF, Sediyama CS (2005) Caracteres morfológicos de soja e braquiária consorciadas sob subdoses de fluazifop-p-butil. Ciência Rural 35(2): 277-283.

Tironi SP, Galon L, Faria AT, Belo AF, Silva AA, Barbosa MHP (2012) Eficiência de uma taxa de herbicida reduzida para controle de Brachiaria brizantha em cana-de-açúcar. Planta Daninha 30(4): 791-798. 